\title{
Recorregut de recerca geològica i mineralògica per les comarques del Pallars Jussà i de I'Alta Ribagorça: des de les Esglèsies a la Mola d'Amunt, Sentís, Sas i a Erta
}

Josep Maria Mata-Perelló

Joaquim Sanz Balagué

\section{XARAGALL \\ REVISTA DE CIÈNCIES DE LA CATALUNYA CENTRAL}

ก. 9

SETEMBRE 2014 


\section{RECORREGUT DE RECERCA GEOLÒGICA I MINERALÒGICA PER LES COMARQUES DEL PALLARS JUSSÀ I DE L'ALTA RIBAGORÇA: DES DE LES ESGLĖSIES A LA MOLA D’AMUNT, SENTÍS, SAS I A ERTA}

\section{Josep Maria Mata-Perelló}

Museu de geologia Valentí Masachs, Escola Politècnica Superior d'Enginyeria de Manresa (EPSEM), Universitat Politècnica de Catalunya · BarcelonaTech (UPC), 08272 Manresa, Spain

\section{Joaquim Sanz Balagué}

Departament d'Enginyeria Minera i Recursos Naturals (EMRN), Escola Politècnica Superior d'Enginyeria de Manresa (EPSEM), Universitat Politècnica de Catalunya - BarcelonaTech (UPC), 08272 Manresa, Spain

Paraules clau: Sistema Pirinenc, Zona Axial Pirinenca, Mantell de les Nogueres, Patrimoni miner

\section{Resum}

Itinerari realitzat el 22 de setembre de 2013. En aquesta ocasió, la totalitat del recorregut de I'itinerari es desenvoluparà per una sola unitat geològica: concretament pel Sistema Pirinenc i més exactament pel Mantell de les Nogueres, en la seva totalitat. Tot i així, en diversos trams centrals del recorregut ens aproparem molt (sense arribar a entrar-hi) a la Zona Axial Pirinenca, o més concretament pels denominats Apilaments antiformes de la Zona Axial Pirinenca.

Així, al llarg del recorregut, trobarem afloraments dels materials mesozoics (del Triàsic) i dels paleozoics (del Devonià, Carbonífer i Permià), que formen part de l'esmentat Mantell de les Nogueres. Aquests materials els anirem trobant al llarg de trot el recorregut de l'itinerari, entre les Esglésies i les immediacions d’Erta.

Per altra banda, cal dir que aquest itinerari es desenvoluparà per dues de les comarques que configuren els Pirineus. Així, s'iniciarà dintre del Pallars Jussà, per on es circularà fins arribar a les immediacions d'Erta. Després, el recorregut entrarà a la comarca de I'Alta Ribagorça, per a finalitzar molt a prop de la població darrerament esmentada, per on finalitzarà el recorregut d'aquest itinerari. 


\section{Objectius fonamentals}

Es centraran en els aspectes geològics, geomorfològics i mineralògics que apuntarem a continuació:

1. Observació dels materials que constitueixen la Unitat de les Nogueres. Aquests materials pertanyen al Carbonífer (amb trams d'esquistos negres, fonamentalment) al Permotries (amb gresos rogencs), i sobretot al Triàsic, en tots els seus trams, especialment al Keuper (amb trams de guixos, argiles i ofites).

2. Observació de les relacions existents entre aquest unitat i la Zona Axial, situada al Nord del recorregut de l'itinerari, tot i que molt propera, en alguns indrets del recorregut central de l'itinerari.

3. Observació dels indrets relacionats amb el patrimoni geològic i miner, que es vagin trobant al llarg del recorregut.

\section{Antecedents}

Pel que fa al recorregut del present itinerari, sols existeixen uns antecedents nostres, relatius al recorregut de l'itinerari, pels voltants de la Mola d'Amunt i de Sentís, es les tracta de: MataPerelló (2009, 2010, 2013a i 2013b). Pel que fa al tram central, entre Sentis i Peranera, no tenim cap antecedent, a excepció de Mata-Perelló (2013c)

Pel que fa a la descripció de les mineralitzacions, cal parlar d'un altre treball, també nostre; en concret de Mata-Perelló (1991). Aquest treball es relatiu a les mineralitzacions catalanes en general, amb un capítol dedicat a la Noguera. També cal fer esment de Mata-Perelló i Sanz (1993).

I pel que fa a l'estructura geològica de la zona per la qual discorre l'itinerari, farem esment de dos treballs, molt interessants, de caràcter generalista. En concret, ens estem referint als següents: Guimerà et altri (1982). i també a Riba et altri (1976). Tots dos treballs es refereixen a la geologia dels Països Catalans, i conseqüentment de Catalunya. Per d'altra banda, també cal fer esment del treball de Rosell (1970); així com de I'IGME (1994).

Tots aquests treballs referenciats, i d'altres, figuren esmentats per ordre alfabètic a l'apartat dedicat a la BIBLIOGRAFIA. 


\section{Recorregut de l'itinerari}

El recorregut de l'itinerari discorrerà inicialment per la comarca del Pallars Jussà, entre les Esglésies, la Mola d'Amunt i Sas. Més endavant, entre Erta i la fi del recorregut, prop d'aquesta mateixa població, es circularà per la comarca de I'Alta Ribagorça, per on finalitzarà el recorregut.

Així, el recorregut s'iniciarà a la localitat de les Esglésies (del terme de Sarroca de Bellera), situada sobre la carretera local $L-513$, procedent de Xerallo. Des d'aquí, el recorregut es dirigirà cap a les immediacions de la Mola d'Amunt. Des d'aquí, s'anirà cap a Sentis i cap a Sas, sense abandonar la comarca del Pallars Jussà. En aquest tram es realitzaran dues aturades.

Després, per un mal camí, el recorregut es dirigirà cap a la població d'Erta, entrant a la comarca de I'Alta Ribagorça. Prop d'aquesta població, finalitzarà aquest recorregut, dintre de la darrera comarca esmentada.

\section{Advertiments previs}

Com en altres recorreguts de RECERCA GEOLÒGICA I MINERALÒGICA... si es disposa del temps suficient, poden efectuar-se passant per totes les parades i filloles. En cas contrari, recomanem prescindir de les anomenades PARADES - CONDICIONALS.

També cal tenir en conte que una part del recorregut final de l'itinerari, es realitzarà per camins de terra, per la qual cosa caldrà prendre les necessàries precaucions, en tot moment del recorregut. Cal dir, que algun tram serà força dolent, com el que va des de Sentis cap a Sas.

Cal tenir, com sempre, una cura molt especial de respecte a la natura, al llarg de tot el recorregut de l'itinerari, i també fora d'ell.

\section{Descripció de l'itinerari}

En aquest recorregut hem situat, com ja és habitual en tots els itineraris, una sèrie d'ESTACIONS o de PARADES, que anirem veient a continuació. En cada cas, els hi donarem una denominació que podrà correspondre a algun paratge proper. També indicarem el terme municipal i la comarca on es troba.

Per d'altra banda, en cadascuna de les parades, indicarem entre parèntesi el número del "Mapa Topográfico", a escala 1:50.000, on es troba situada la parada considerada. En aquesta ocasió sols utilitzarem dos fulls, concretament: el $\mathbf{2 1 3}$ (o del Pont de Suert) i el $\mathbf{2 1 4}$ (o de Sort).

Així doncs, la relació ordenada de les parades que composen aquest recorregut, és la següent. 


\subsection{Parada 1 - CONDICIONAL. AIGUABARREIX DE LA VALIRI I EL RIU DE MANY ANET, (la Mola d'Amunt, actual terme de Sarroca de Bellera de la comarca del Pallars Jussà i abans del de Benes, de I’Alta Ribagorça). (Full 214).}

Tot i que el recorregut de l'itinerari haurà començat al poblet de les Iglésies, haurem anat cap cap a aquest indret, on començarà en realitat el recorregut de l'itinerari. Aquest indret es troba molt prop del poblet de la Mola d'Amunt, dintre de l'actual terme municipal de Sarroca de Bellera. Aquest indret es troba prop de l'aiguabarreig del Valiri, que ve per llevant i del riu Manyanet, que baixa del Nord, del poble del mateix nom.

Aquest indret es troba plenament situat dintre del Mantell de les Nogueres, al nord de I'Encavalcament de Buira. Així, en aquest lloc, estem veient aflorament dels materials triàsics del Buntsandsteim, amb nivells de gresos, fonamentalment. Prop d'aquí, aigües amunt, hi afloren els materials rogencs del Permotries, molt similars als que ara estem veient.

\subsection{Parada 2. CAMí DE LA MOLA D'AMUNT CAP A SENTíS, A UNS 1'5 Km DE SENTís, (Sentís, actual terme de Sarroca de Bellera de la comarca del Pallars Jussà i antigament del terme de Benes, de l'Alta Ribagorça). (Full 214).}

Després de fer l'aturada anterior, cal fer un altre petit recorregut, per tal d'arribar fins a les immediacions de Sentís. Poc abans d'arribar-hi, caldrà fer una nova aturada d'aquest itinerari. Així, des de la parada anterior, haurem recorregut uns 2' $5 \mathrm{Km}$, aproximadament.

En aquest recorregut, hem anat trobant afloraments del Triàsic Superior. Així, s'hauran fet palesos els materials del Keuper, en molts trams del recorregut. Tot i així, en diversos trams s'han fet palesos els nivells rogencs del Permotries, amb trams de gresos i calcolutites, fonamentalment. Cal dir que haurem estat circulant sempre pel Mantell de les Nogueres. Per d'altra banda, en aquest tram hem superat l'Encavalcament de Buira, de direcció WNW - ESE. Així, en aquest lloc es troba un d'aquests afloraments, podent-se fer una nova aturada, per tal de reconèixer aquests materials del Permotries.

\subsection{Parada 3 - CONDICIONAL. COLLET DE SENTIS, (Sentís, de l'actual terme de Sarroca de Bellera de la comarca del Pallars Jussà, i antigament del propi terme de Benes, de l’Alta Ribagorça). (Full 214).}

Després de fer l'aturada anterior, cal arribar fins al poblet de Sentís, després ens caldrà continuar per la pista que es dirigeix cap el poblet de Sas, d'aquest mateix municipi. En arribar al Collet de Sentis, farem una nova aturada, a uns $2^{\prime} 5 \mathrm{Km}$ de l'anterior.

En aquest recorregut, hem continuat dintre del Mantell de les Nogueres. Així, en aquest tram de I'itinerari, hem anat trobant els materials ja esmentats anteriorment. També, prop de Sentís, haurem vist un aflorament de les ofites. I més endavant els gresos rogencs del Buntsandsteim i els gresos del Permotries. En aquest indret apareixen afloraments d'aquests darrers materials. (fotografia 1). 


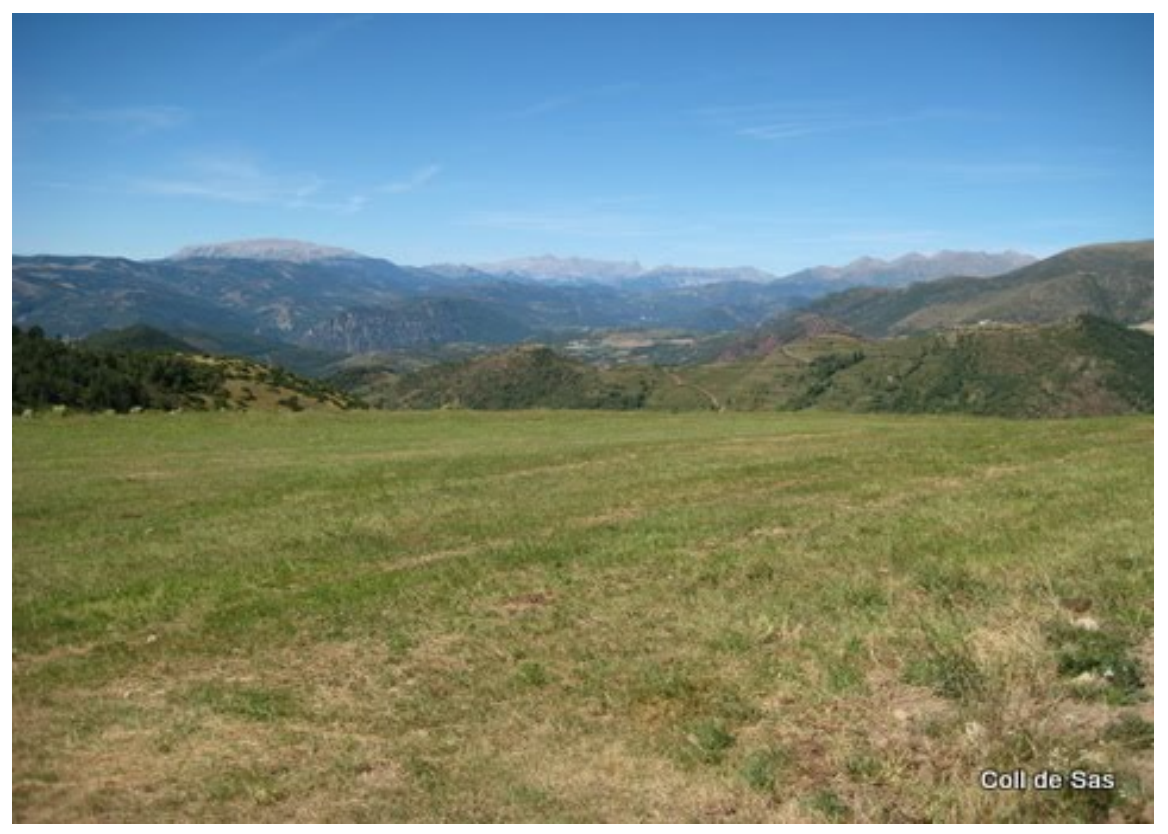

Fotografia 1. Immediacions del Collet de Sentis

\subsection{Parada 4. COLLET DE SAS, (Sentís i Sas, de l'actual terme de Sarroca de Bellera de la comarca del Pallars Jussà, i antigament del propi terme de Benes, de I’Alta Ribagorça). (Full 214).}

Després de fer l'aturada anterior, cal continuar per la pista que es dirigeix cap el poblet de Sas, d'aquest mateix municipi. En arribar al Collet de Sas, farem una nova aturada, a uns 0'8 Km de I'anterior.

En aquest recorregut, hem continuat dintre del Mantell de les Nogueres. Per d'altra banda, prop del collet, hem travessat I'Encavalcament de Benes, de clara direcció WNW - ESE, clarament pirinenca. Així, en aquest tram de l'itinerari, hem anat trobant els materials ja esmentats anteriorment: els gresos rogencs del Buntsandsteim i els gresos del Permotries. En aquest indret apareixen els materials rogencs del Buntsandsteim. (fotografia 2). 


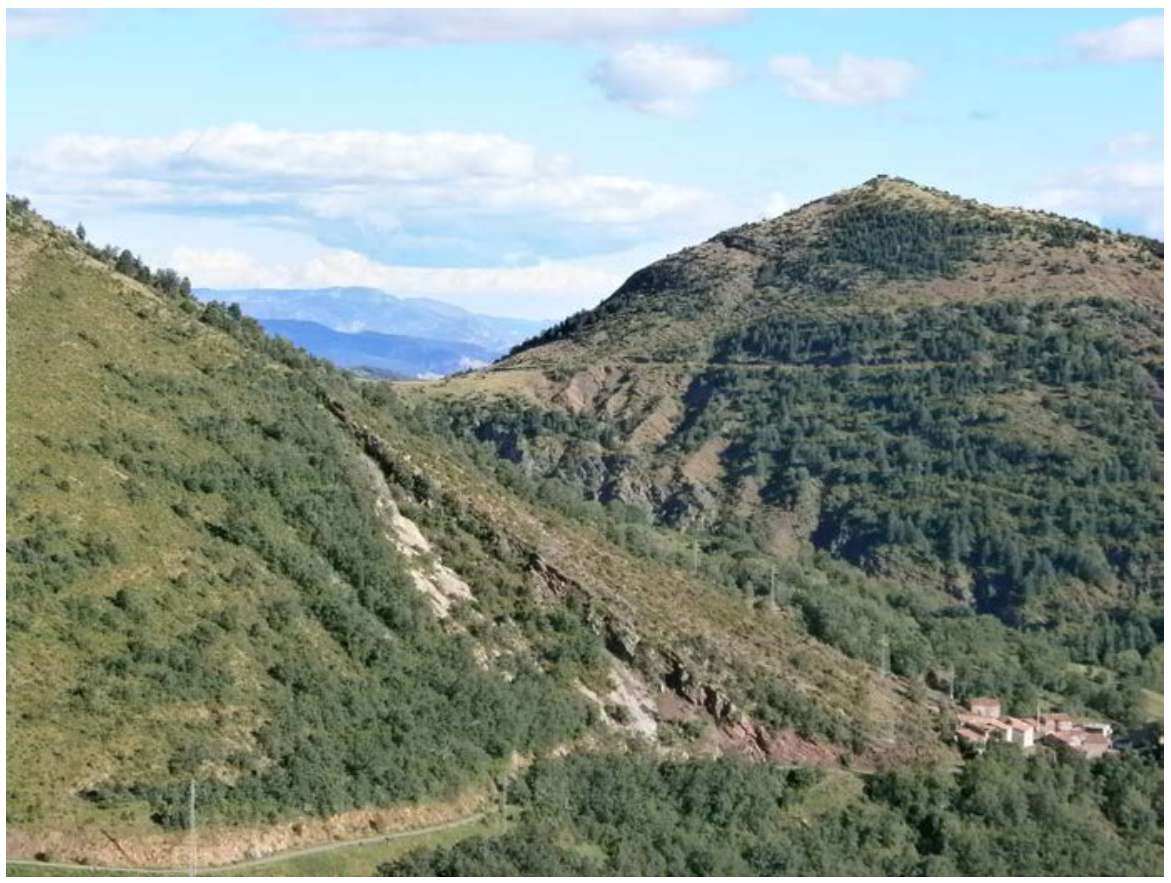

Fotografia 2. Collet de Sas. A la dreta, hi ha dalt els materials del Permotries i els del Carbonífer a sota. A l'esquerra, es torna a repetir el contacte. Per sota, es veu el poble de Sas. Agost del 2013

En aquest recorregut, molt prop del collet, també haurem vist uns afloraments dels materials carbonosos de la Formació Erill Castell. Aquests es fan especialment palesos poc abans d'arribar al collet. (fotografies 3 i 4).

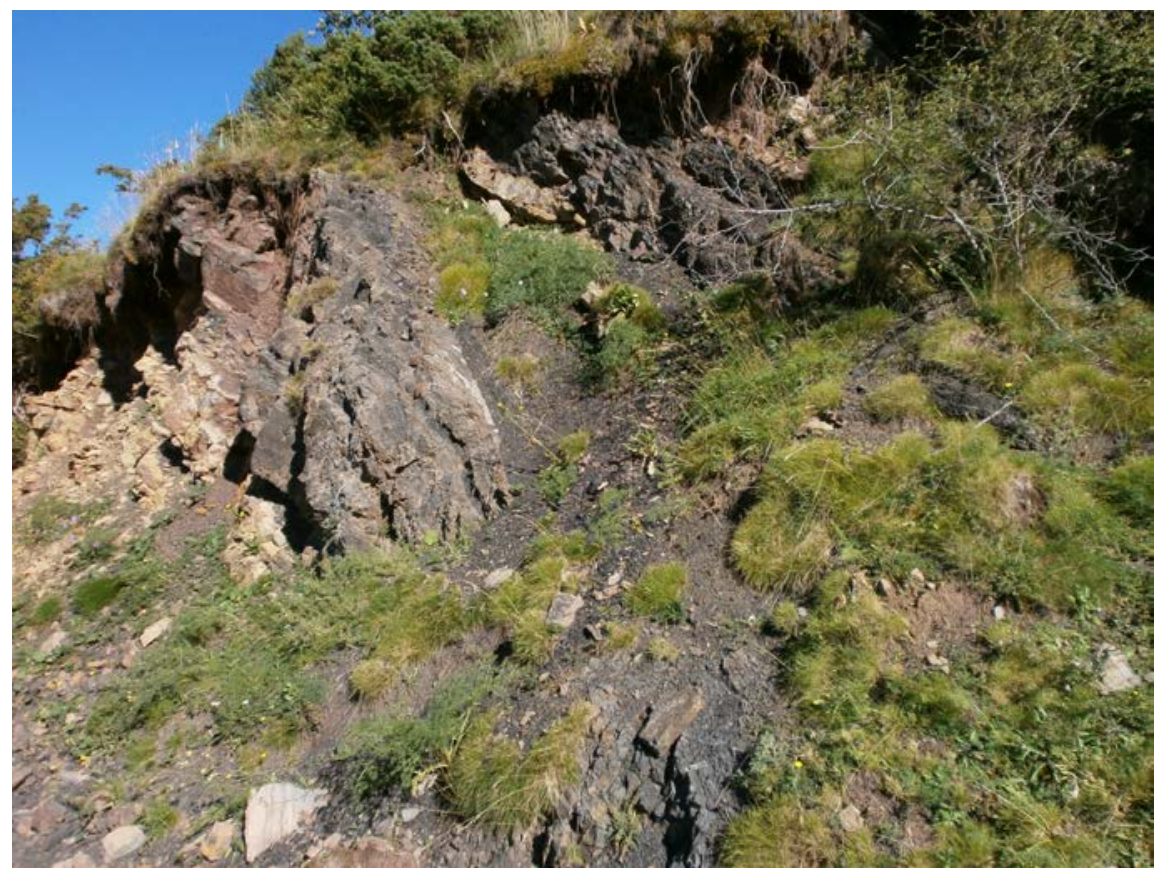

Fotografia 3. Collet de Sas. Aflorament dels materials del Carbonífer / 7 d’Agost del 2013 


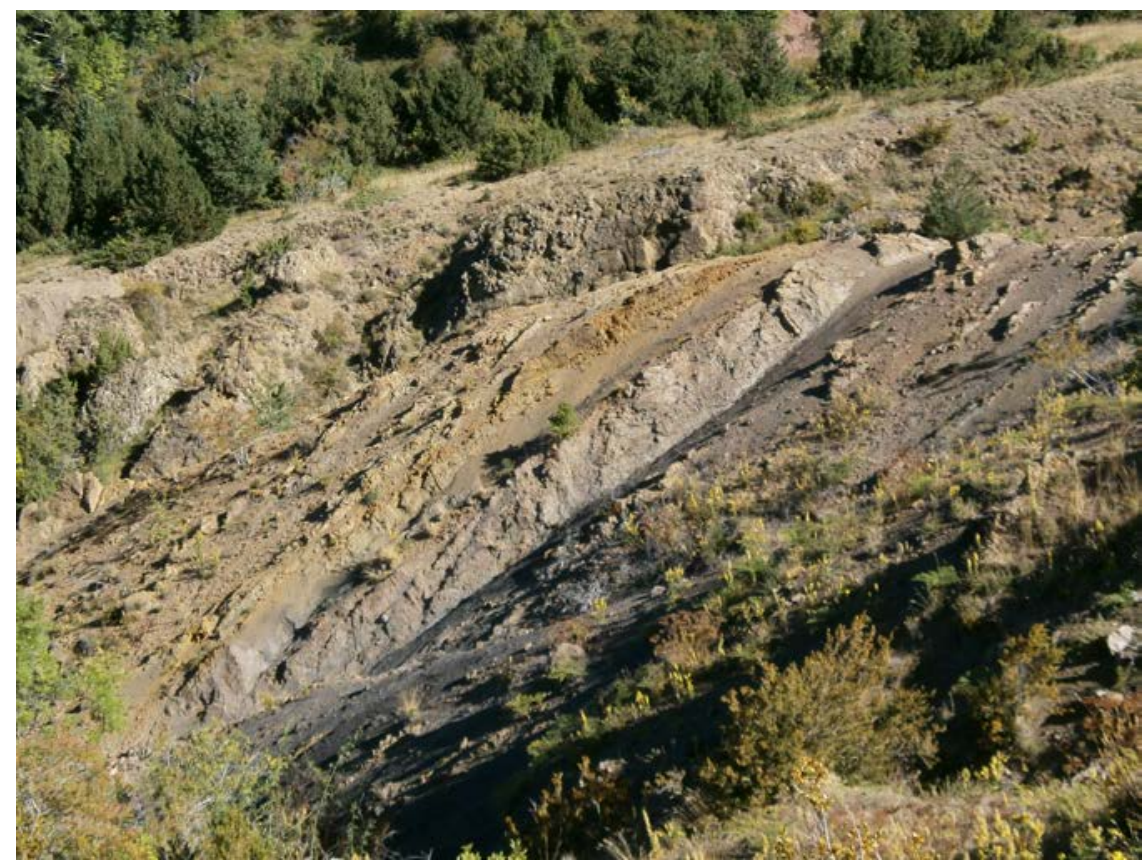

Fotografia 4. Collet de Sas. Aflorament dels materials del Carbonífer, setembre del 2013

Per altra banda, en aquest recorregut, s' han fet evidents els relleus de ponent, de la comarca de la Ribagorça. Així, haurem vist el Turbó, entre altres indrets. (fotografia 5).

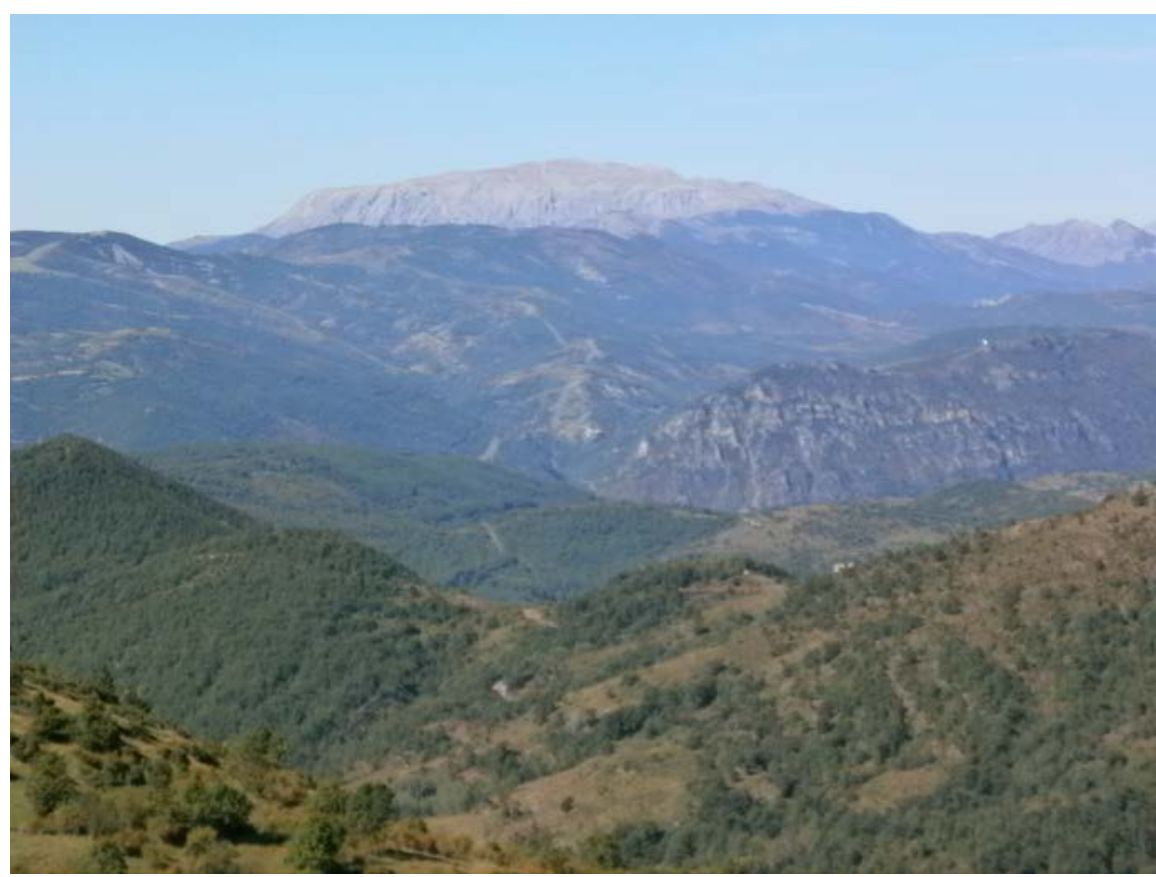

Fotografia 5. El turbó, des del Collet de Sas. Setembre del 2013 


\subsection{Parada 5. RIUET DEL PORT D’ERTA, (Erta, actualment és del terme municipal de Pont de Suert i antigament era del terme de Malpàs, comarca de I’Alta Ribagorça). (Full 214).}

Des de la parada anterior, cal continuar cap el Nord (i cap el NW). Així, aviat passarem pel poblet de Sas i més endavant arribarem a Erta. Després, ens caldrà continuar per la pista forestal que condueix cap a Castellars i cap a Malpàs. A uns 1'5 Km d'Erta i a uns 4 des de la parada anterior, efectuarem una nova aturada.

En aquest recorregut, hem continuat circulant dintre del Mantell de la Noguera. Així, després de creuar I'Encavalcament de Sas, haurem continuat trobant afloraments dels materials esmentats anteriorment. Tot i així, prop de Sas, haurem trobat afloraments dels materials carbonatats (i dels pissarrencs, ocasionalment) del Devonià. Aquests materials carbonatats són els que apareixen per l'indret de l'aturada. Tot i que es troben recoberts per materials cenozoics, neògens del Pleistocè, de procedència glacial.

Així, amb aquest tram del recorregut, ens hem estat aproximant a la Zona dels Apilaments Antiformes de la Zona Axial Pirinenca, la qual s'estén al Nord d'on ara estem situats, fonamentalment pel Port d'Erta.

En aquest indret, es pot veure el riuet del Port d'Erta, el qual baixa de la coma del Port d'Erta, situada dintre del terme de Sarroca de Bellera. Cal dir que aquesta coma és en realitat un petit circ glacial, situat a unes 3 hores d’Erta, aigües amunt. (fotografies 6 i 7).

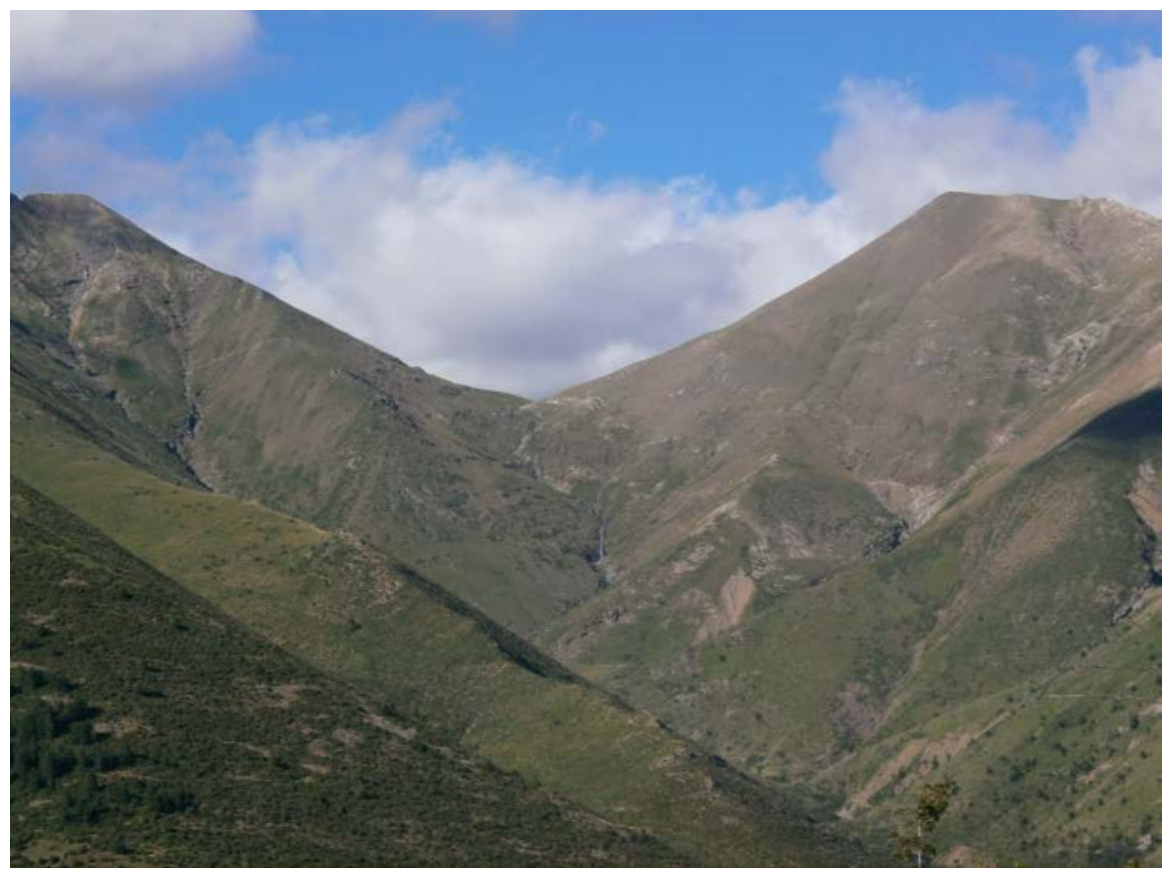

Fotografia 6. Pas d’Erta, entre afloraments de materials del Devonià. 7 d’Agost del 2013 


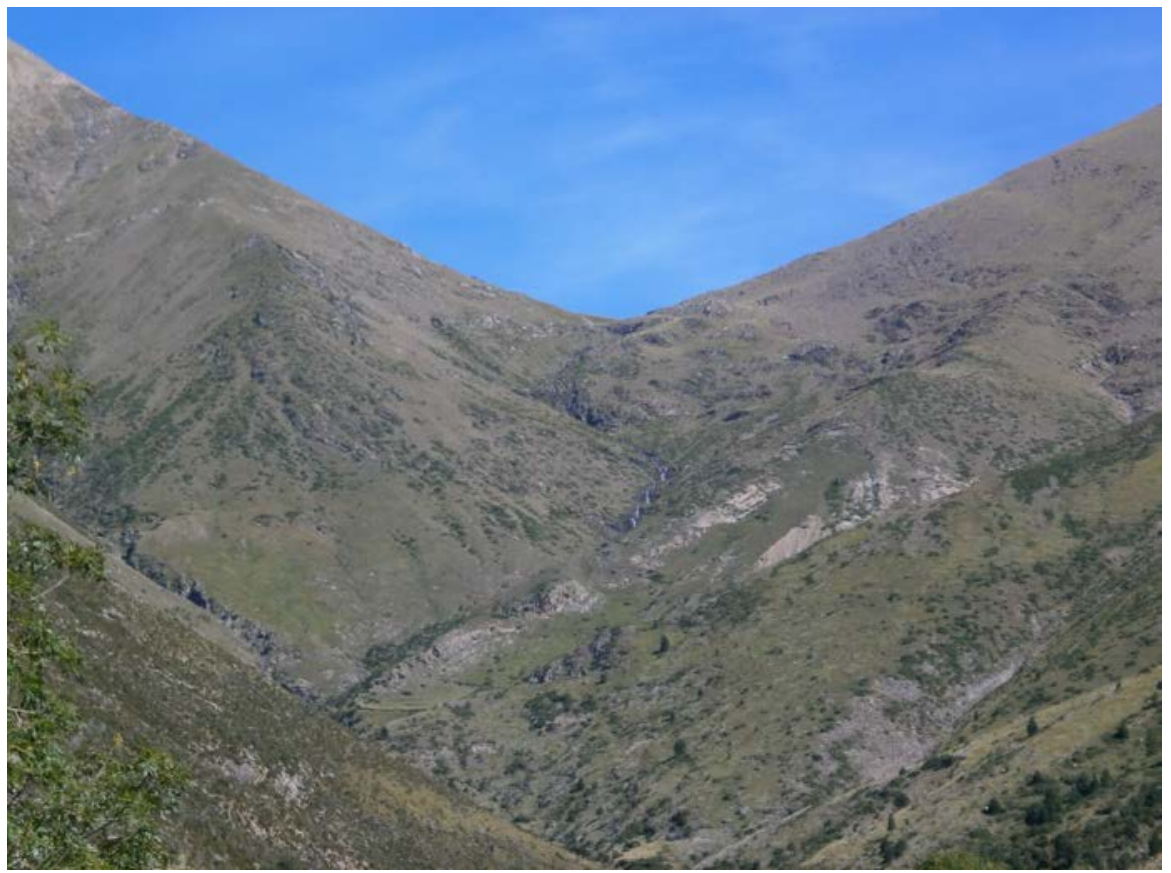

Fotografia 7. El Pas d’Erta, entre afloraments de materials del Devonià. Setembre del 2013

Des d'aquest indret, mirant cap el NW, es fan evidents les estructures del Pic Cervi, amb un plec situat al seu cim, desenvolupat sobre els afloraments de les calcaries del Devonià. (fotografia 8). Evidentment, es tracta d'un interessant sinclinal, molt visible des de l'indret de la present aturada.

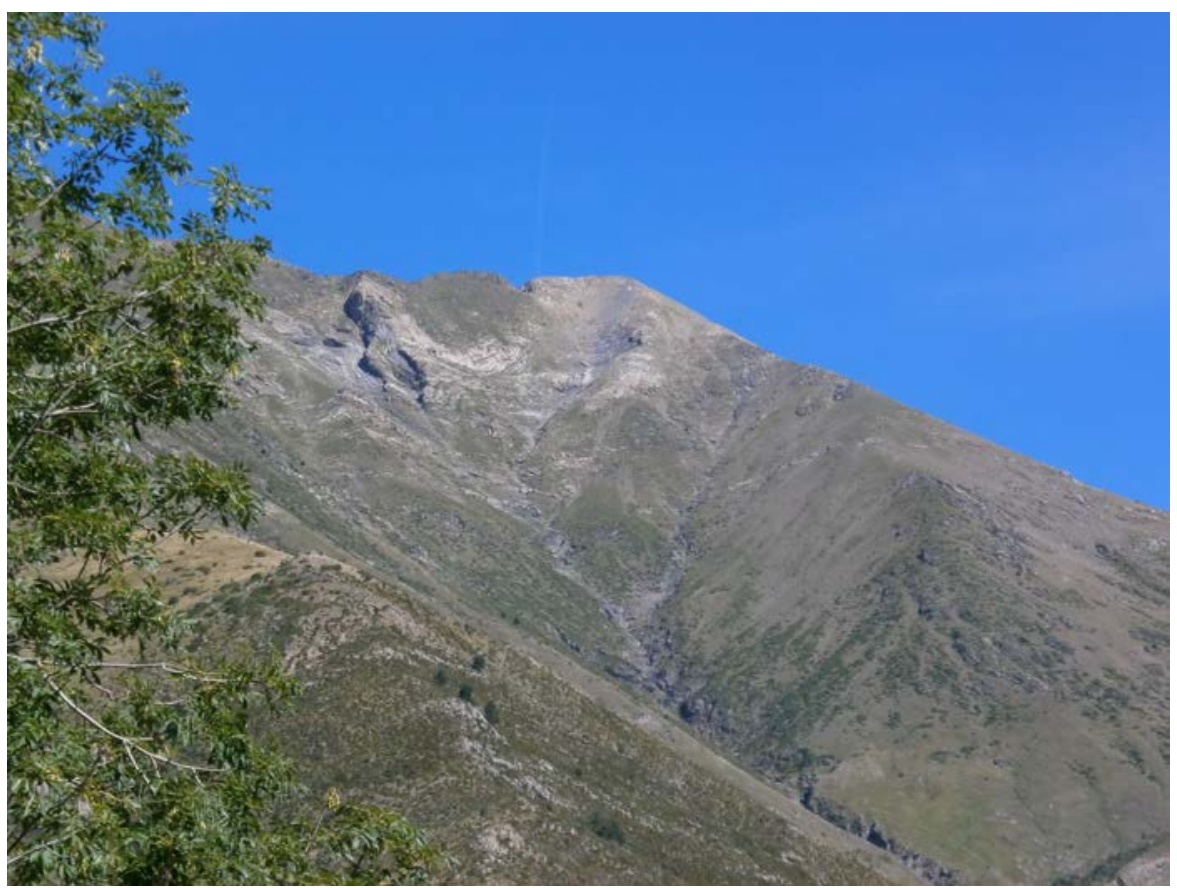

Fotografia 8. El plec del Pic Cervi, entre els afloraments de materials del Devonià. Setembre del 2013 
Finalment, cal dir que aquest riuet (el Riu d'Erta), aigües avall es un afluent del riu de Peranera (o Noguera de Peranera, que circula per la Vall de Malpàs). Per la seva banda, aquest riu, al seu moment també és un afluent del Noguera Ribagorçana, molt prop del Pont de Suert, al Monestir de Lavaix

En aquest indret finalitza el recorregut de l'itinerari.

\section{Bibliografia}

GUIMERÀ, J. et altri (1992).- Geologia (II), Història Natural dels Països Catalans, Vol. 2, 547 pag. Enciclopèdia Catalana, S.A. Barcelona.

IGME (1994).- Mapa Geológico de España a escala 1:50.000 (Plan Magna). Fulla i Memòria ${ }^{\circ}$ 252 (Tremp). Inst. GeoMinero y Tecnol. España. Minist. Indústria. Madrid.

MATA-PERELLÓ, J.M. (1991).- Els Minerals de Catalunya. Arxius de la Secció de Ciències de I'Institut d'estudis Catalans, vol.47, 545 pàgines. Barcelona.

MATA-PERELLÓ, J.M. (2009).- Recorregut de recerca geològica i mineralògica per les comarques del Pallars Jussà i de l'Alta Ribagorça: des de Senterada a Xerallo i al Pont de Suert. Inèdit. 10 pàgines. Manresa.

MATA - PERELLÓ, J. M. (2010).- Recorregut de recerca geològica i mineralògica per les comarques del Pallars Jussà i de l'Alta Ribagorça: des de la Pobla de Segur a Senterada, Xerallo i al Pont de Suert. Inèdit. 10 pàgines. Manresa.

MATA - PERELLÓ, J. M. (2013a).- Recorregut de recerca geològica i mineralògica per la comarca del Pallars Jussà: des de la Pobla de Segur a Senterada, Sarroca de Bellera, a Xerallo i a la Vall de Manyanet. Inèdit. 12 pàgines. Manresa.

MATA - PERELLÓ, J. M. (2013b).- Recorregut de recerca geològica i mineralògica per la comarca del Pallars Jussà: des de Xerallo a la Mola d'Amunt i a Manyanet. Inèdit. 10 pàgines. Manresa.

MATA - PERELLÓ, J. M. (2013c).- Recorregut de recerca geològica i mineralògica per les comarques del Pallars Jussà i de l'Alta Ribagorça: des de la Mola d'Amunt a Sentís, Sas, Erta, Peranera i a Malpàs. Inèdit. 14 pàgines. Manresa.

MATA-PERELLÓ, J.M. i SANZ BALAGUÉ, J. (1993).- Guía de identificación de Minerales, adaptada fundamentalmente a la Península Ibérica. Parcir, Edic. Selectas, 243 pàgines. Manresa.

RIBA ARDERIU, O. et altri (1976).- Geografia Física dels Països Catalans. Edit Ketres. 211 pàgines. Barcelona.

ROSELL SANUI, J. (1970).- Explicació del Mapa Geològic, a escala 1:50.000, corresponent al full no 252 (Tremp). Mapa Geológico de España. Inst. Geológico y Minero de España. Madrid. 